\author{
Мартиновський В.C. \\ кандидат економічних наук, доцент \\ E-mail: martinv@i.ua \\ Бурага Л.С. \\ магістрант \\ кафедра економіки промисловості \\ Одеська національна академія харчових технологій, \\ вул. Канатна, 112, м. Одеса, Україна, 65039 \\ E-mail: mila.buraga@yandex.ru
}

\title{
ЕФЕКТИВНІСТЬ БАНКІВСЬКОГО КРЕДИТУВАННЯ МАЛОГО ТА СЕРЕДНЬОГО БІЗНЕСУ В УКРАЇНІ
}

\begin{abstract}
Статтю присвячено дослідженню ефективності банківського кредитування малого та середнього бізнесу в Україні. Проаналізовано кількість та якість наданих кредитів суб'єктам господарювання; розглянуто суми наданих кредитів в розрізі областей та секторів економіки; проаналізовано розмір річних відсотків по кредитах. Виявлено основні недоліки в сфері кредитування малого та середнього підприємництва. Внесені пропозиції щодо підвищення ефективності кредитування малого та середнього бізнесу.

Ключові слова: малий та середній бізнес, банківські кредити, статистика НБУ, відсотки, фрі-
\end{abstract} нансування, державна підтримка.

This work is licensed under a Creative Commons Attribution 4.0 International License http://creativecommons.org/licenses/by/4.0/

Постановка проблеми та її зв'язок з важливими науковими та практичними завданнями. В умовах необхідності стабілізації та розвитку економіки України важливого значення набуває проблема фінансового забезпечення діяльності суб'єктів малого та середнього господарювання, фінансові ресурси яких є доволі обмеженими. Одним з важливих джерел фінансування малого підприємництва є позики банків. Успішність діяльності малих підприємств останнім часом дедалі тісніше залежить від ступеня залучення кредитних ресурсів банківських установ до системи фінансового забезпечення поточної діяльності. Таким чином, банки стають одними з учасників фінансування розвитку малого та середнього бізнесу, забезпечуючи не тільки його фінансування, а й зв'язок між всіма учасниками - державою, інвестиційними фондами, великими підприємствами та споживачами продукції.

Актуальність дослідження цих проблем посилюється ще й тим, що повільність і суперечливість процесів подолання кризових явищ в економіці України значною мірою зумовлена саме недооцінкою ролі та значення малого та середнього бізнесу як соціально-економічного фундаменту, без якого не може стало розвиватися будь-яка інноваційно-орієнтована, а особливо європейська держава.

Аналіз останніх публікацій по проблемі. Дослідженням різних аспектів банківського кредитування малого та середнього бізнесу займалися як зарубіжні, так і вітчизняні вчені-економісти. Зокрема: Ф. Аллен, Дж. Акерлоф, Р. Бауер, Дж. Бенстон, Дж.
Герлі, Д. Даймонд, Х. Деріга, В. Балюк, О. Білоус, О. Вовчак, М. Крупка, А. Мороз, С. Реверчук, С. Савлук, Я. Чайковський, Н. Шелудько, В. Ковальов, А. Ольшанський та інші.

Так, Я. Чайковський відмічає, що суттєвим важелем регулювання розвитку малого і середнього бізнесу є надання йому кредитної підтримки, без чого він просто виявиться неконкурентоспроможним порівняно 3 великими підприємствами, концернами чи об'єднаннями, оскільки малі фірми не мають можливості надавати необхідні фінансові гарантії, а тому й одержувати в банках кредити, брати широку участь в лізингових операціях [1].

Варто зазначити, що в умовах кардинальних змін в економіці та обмежених можливостях фінансування державою розвитку малого та середнього бізнесу, виникає необхідність розвивати банківське кредитування.

Формулювання цілей дослідження. Метою статті є аналіз ефективності кредитування малого та середнього бізнесу та обгрунтування практичних рекомендацій щодо підвищення ролі банківських установ у формуванні фінансового забезпечення процесів розвитку малого та середнього бізнесу. Для досягнення мети дослідження було вирішено такі завдання: визначити частку малого та середнього бізнесу в загальній кількості підприємств, проаналізувати суми наданих банківських кредитів у розрізі регіонів та секторів економіки, розглянути середні річні ставки по кредитах в банках України та запропонувати рекомендації щодо підвищення ефективності надання 
кредитних коштів банками на розвиток малого та середнього підприємництва в Україні.

Виклад основних матеріалів та їх обгрунтування. Згідно Державного комітету статистики в 2014 році в Україні налічувалося 1932161 суб'єктів господарювання, з яких 497 суб'єктів великого підприємництва, 16618 суб'єктів середнього підприємництва і 1915046 суб'єктів малого підприємництва. Хоча в 2013 році ці показники становили: 1722070 всьо- го суб'єктів господарювання, 3 яких 659 суб'єктів великого підприємництва, 19210 суб'єктів середнього підприємництва та 1702201 суб'єктів малого підприємництва. Отже, загальна кількість суб'єктів господарювання збільшилася на 13,51\%, але збільшення відбулося лише в сфері малого бізнесу на 12,50\%, великий та середній бізнес зменшився на $24,58 \%$ та 13,49\% відповідно (табл. 1).

Кількість суб'сктів господарювання в Україні в 2013-2014 роках *

Таблиця 1

\begin{tabular}{|l|c|c|c|c|c|}
\hline & 2013 рік & 2014 рік & $\begin{array}{c}\text { Відносне } \\
\text { відхилення,\% }\end{array}$ & $\begin{array}{c}\text { Частка від загальної } \\
\text { кількості } \\
\text { господарств,\% }\end{array}$ \\
\hline Усього суб’єктів господарювання & 1722070 & 1932161 & $+13,51 \%$ & \multicolumn{3}{|c|}{100} \\
\hline Суб’єкти великого підприємництва & 659 & 497 & $-24,58 \%$ & 0,04 & 0,03 \\
\hline Суб’єкти середнього підприємництва & 19210 & 16618 & $-13,49 \%$ & 1,12 & 0,86 \\
\hline Суб’єкти малого підприємництва & 1702201 & 1915046 & $+12,50 \%$ & 98,84 & 99,11 \\
\hline
\end{tabular}

*Розраховано авторами з використанням джерел [2]

Як бачимо, частка суб'єктів малого господарювання становить 98,84\% загальної кількості підприємництв по Україні, тоді як середнє та велике підприємництво становить лише $0,03 \%$ та $0,86 \%$.

Отже, малий бізнес багато в чому визначає темпи економічного зростання, структуру і якість внутрішнього валового продукту. Основна його функція, яка є надзвичайно важливою - соціальна. Це створення робочих місць, професійне навчання. Мале підприємництво як самостійний і незамінний елемент ринкової економіки істотно впливає на структурну перебудову в економіці країни, робить певний внесок у збільшення загальних обсягів виробництва, роздрібного товарообігу, сприяє економії та раціональному використанню ресурсів, створює сприятливе середовище для розвитку конкуренції та усунення монополізму в здійсненні підприємницької діяльності, забезпечує стимули до інноваційних процесів та високоефективної праці. Також, малий та середній бізнес має певні переваги - мобільність, здатність швидко пристосовуватися до змін споживчого попиту, гнучкість, раціональну організаційну структуру підприємства, оперативність освоєння випуску нової продукції малими партіями, невеликі експлуатаційні витрати [8].

Як зазначено вище, малий та середній бізнес сприяє економічному зростанню, створенню нових робочих місць, подоланню бідності та розвитку інновацій, але при цьому має обмежений доступ до фінансових ресурсів у порівнянні з великими підприємствам. Сьогодні для малих і середніх господарств України внутрішнє фінансування не є головним джерелом фінансування, оскільки розміри прибутків є невеликими. Крім того, собівартість вітчизняного виробника так завантажена надбавками, що сподіватися йому на високий прибуток не доводиться. Національний виробник у наш час $є$ абсолютно незахищеним від дешевого імпорту. Тому більшість підприємництв за фінансуванням звертаються за позиками до комерційних банків.

У результаті кризи (2008 рік) кредитування малого та середнього бізнесу значно скоротилося через фінансові труднощі підприємств. У найскладніші роки банки зосереджувалися на роботі з корпоративним та роздрібним сегментами. Щодо клієнтів сектору малого та середнього підприємництва, банки переважно зосередилися на стабілізації кредитних портфелів та їх помірному зростанні, фокусуючи свою увагу на інших видах доходів, окрім кредитування. Зараз банки відновлюють інтерес до кредитування даного сегменту клієнтів, про що свідчить поступове зростання кількості банків, які надають спеціальні кредитні продукти для малого та середнього бізнесу, та щорічне зростання загальної суми виданих кредитів банками (рис.1).

Так, сума виданих кредитів суб'єктам господарювання у 2015 році склала 802582 млн.грн., що на 14,86\% більше порівняно з 2014 роком (698777 млн.грн). Тоді як сума виданих кредитів фізичним особам у 2015 році склала 179040 млн.грн., що на $6,72 \%$ більша порівняно 32014 роком (167773 млн.грн.) [3].

Згідно статистики НБУ, на кінець червня 2016 року підприємцям видано кредитів на суму 779362 млн.грн. Найбільше кредитів видано в Київській області та м. Києві (474510 млн.грн. - 60,88\%), на другому місці Дніпропетровська область (172157 млн.грн. - 22,09\%). В Одеській області видано лише $2,78 \%$ банківських кредитів по Україні (21673 млн.грн.) [3]. Найменшу суму кредитів видано в Чернівецькій області 673 млн.грн. ( рис.2). Це свідчить про нерівномірність економічного розвитку країни. Всі великі бізнес-проекти зосереджені в столиці та в декількох великих містах, тоді як віддалені міста залишаються економічно непривабливими для ведення бізнесу. 


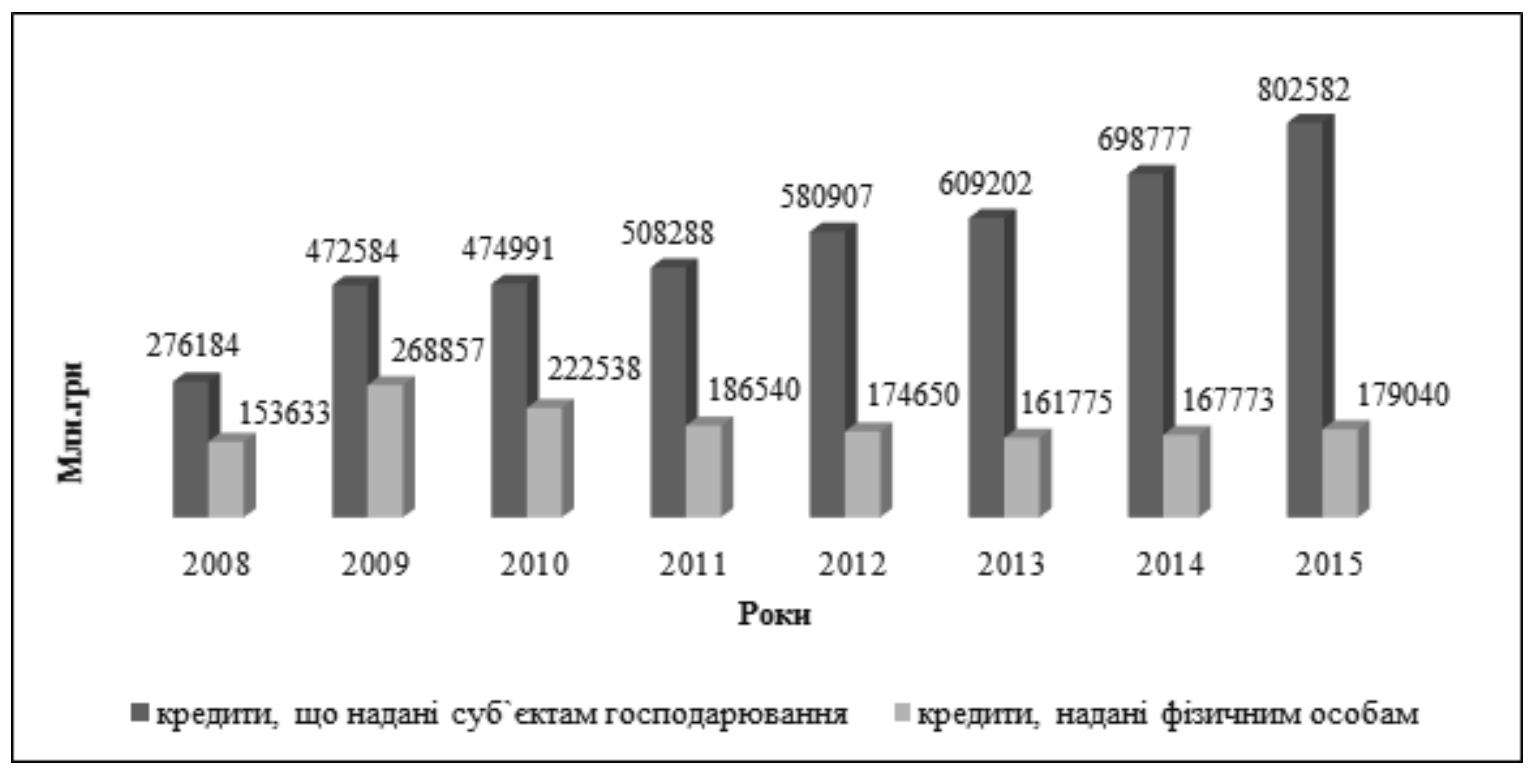

Рис.1 Динаміка наданих кредитів банками за 2008-2015 роки (млн.грн.)*

*Узагальнено авторами з використанням джерел [3]

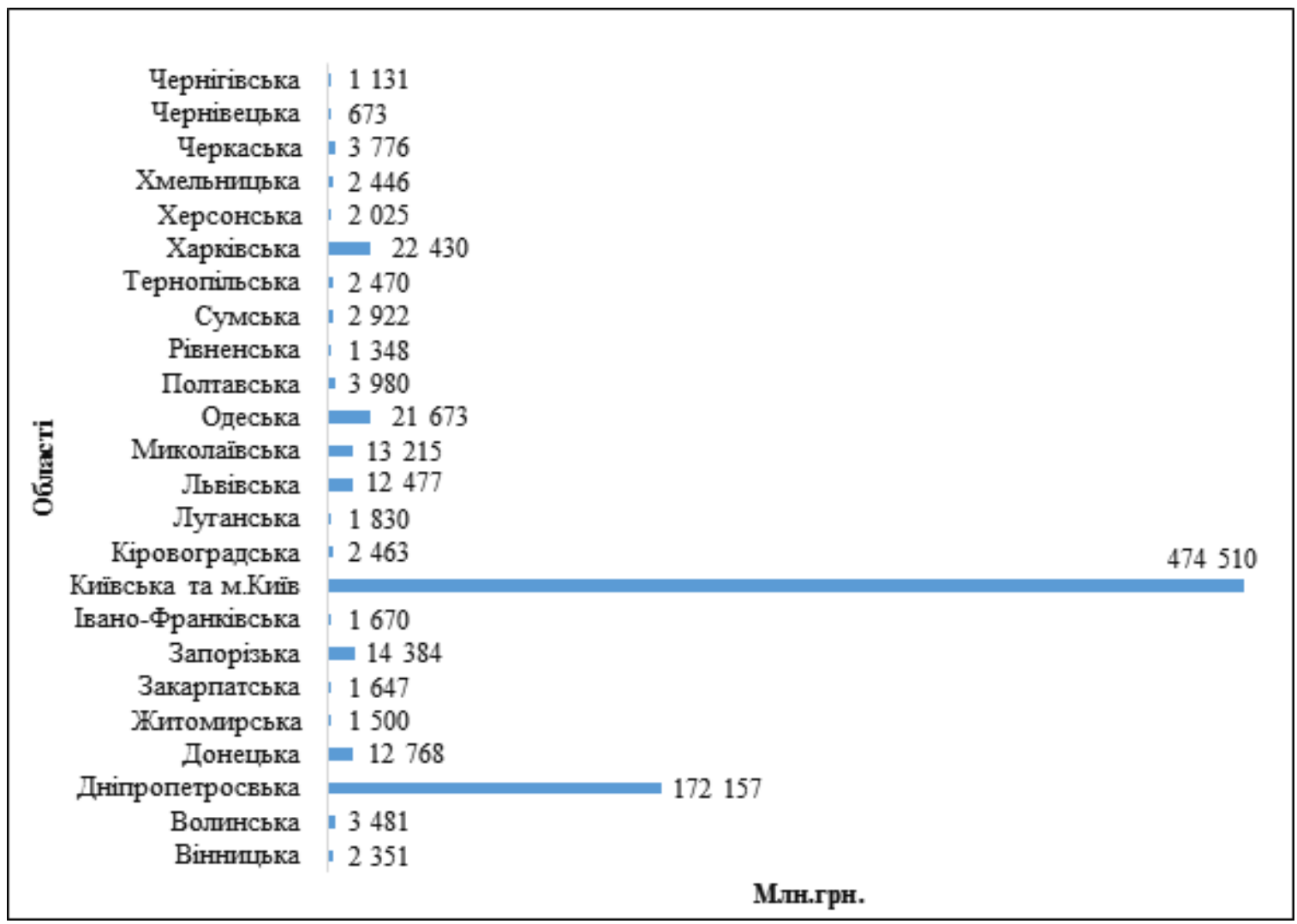

Рис.2. Кредити надані суб’єктам господарювання, у розрізі регіонів на кінець червня 2016 року (млн.грн.)*

*Узагальнено авторами з використанням джерел [3]

Якщо розглядати кредити надані банками в розрізі секторів економіки України (рис.3), то ми відмітимо таку тенденцію: $33,57 \%$ всіх кредитів надано на оптову та роздрібну торгівлю, ремонт автотранспортних засобів; 25,15\% - на переробну промисловість; 9,67\% - операції з нерухомістю, і лише 7,28\% в сільське, лісове та рибне господарство, що дуже i дуже мало, та свідчить про недостатній розвиток цьо- го сектору економіки (не дивлячись на велику кількість «Агрокредитів» в банках України). Основним бізнесом малих господарств в країні є торгівля. I на нашу думку, держава повинна підтримувати та заохочувати підприємства, які займаються виробництвом продукції або ж продуктами, які зменшують імпорт. 


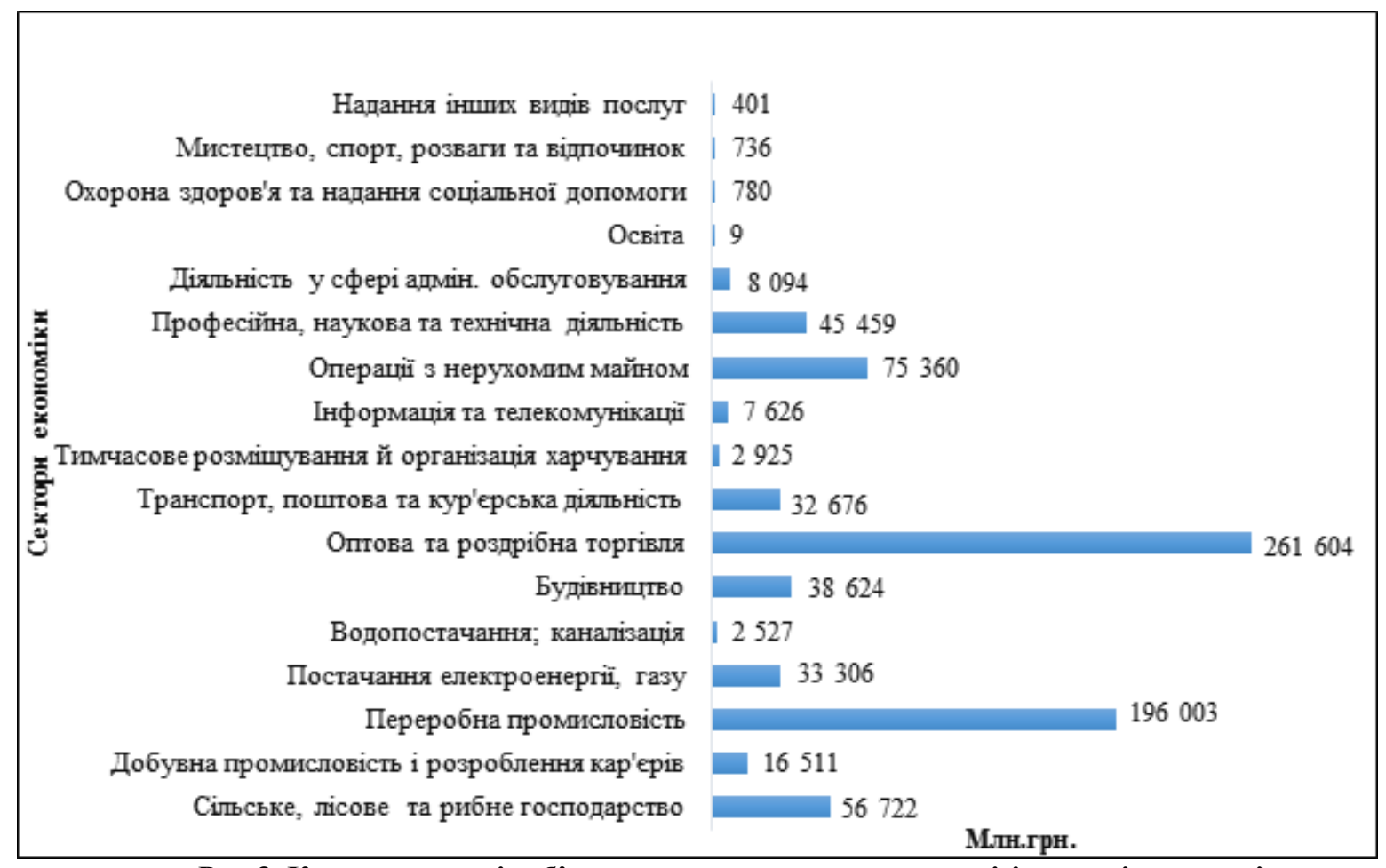

Рис.3. Кредити надані суб’'сктам господарювання, у розрізі секторів економіки, станом на кінець червня 2016 року(млн.грн.)*

*Узагальнено авторами авторами з використанням джерел [3]

Що стосується відсотків по кредитам для малого та середнього бізнесу, то вони дуже високі порівняно 3 європейськими країнами. Так, наприклад, в Німеччині при терміні кредитування в 5 років ефективна відсоткова ставка складає 2,63\%. Виплата кредиту та відсотків починається через рік після оформлення кредиту.А при терміні в 10 років ефективна відсоткова ставка складає 2,89\%. Виплата кредиту та відсотків починається через два роки після оформлення кредиту. В Україні ж відсоткові ставки коли- ваються в діапазоні 18-35\% річних (табл.2), а середній термін кредитування становить 5 років. При цьому існують всілякі комісійні винагороди. Наприклад, комісія при розгляді заявки - 500 грн., щомісячна комісія за розрахункове обслуговування - 0,5-1,5\%, разова комісія - 0,5-1,5\%. Також основною умовою при видачі кредитних коштів $є$ перший внесок в розмірі 10-50\% від суми кредиту. Все це стримує підприємців від оформлення позик в банках України, і підштовхує їх звертатися за позиками закордон.

Таблиця 2

Розмір відсоткових ставок по кредитах для середнього та малого підприємництва в банках України *

\begin{tabular}{|l|c|c|c|}
\hline \multirow{2}{*}{ Назва банку } & \multicolumn{3}{|c|}{ Розмір відсотків за видами кредитування,\% } \\
\cline { 2 - 4 } & Овердрафт & $\begin{array}{c}\text { Кредит на поповнення } \\
\text { обігових коштів }\end{array}$ & Інвестиційний кредит \\
\hline Приватбанк & $27-29 \%$ & $30-34 \%$ & $27-28 \%$ \\
\hline Ощадбанк & $19,5 \%$ & $24,5 \%$ & $19,75 \%$ \\
\hline Кредобанк & $18,5 \%$ & $20,5 \%$ & $21-22 \%$ \\
\hline $\begin{array}{l}\text { Райффайзен } \\
\text { банк Аваль }\end{array}$ & $22-23 \%$ & $20-21 \%$ & $26 \%$ \\
\hline Юнікредитбанк & $28 \%$ & $26 \%$ & $19 \%$ \\
\hline
\end{tabular}

*Узагальнено авторами з використанням джерел [7]

В цілому, розвиток системи кредитування малого бізнесу з боку комерційних банків в нашій країні стикається з багатьма проблемами, серед яких:

- великі відсоткові ставки по кредитах; риємців;

- недостатність стартового капіталу у підп-

- відсутність необхідного заставного забезпечення у малих підприємств; 
- дуже короткі строки погашення кредиту;

- непрозора і недостовірна звітність й низька фінансова грамотність керівників малих підприємств;

- відсутність якісних бізнес-планів;

- відсутність фінансової та бухгалтерської звітності;

- низька частка у підприємців власного капіталу у бізнесі (у окремих випадках 5-15\%);

- відсутність кредитної історії для підприємців-початківців (старт-апів);

- невідповідність фінансової звітності підприємців, які працювали за спрощеною системою оподаткування, вимогам банків (у цьому випадку можливе надання кредиту як фізичній особі, під заставу, але при цьому набагато вищі відсотки);

- неплатоспроможність деяких підприємців;

- законодавча неврегульованість на ринку мікрофінансування.

Для їх вирішення, на думку автора, потрібна активна участь як держави так і банківських установ у сприянні розвитку малого та середнього бізнесу. Так, українській банківській системі потрібно використовувати досвід розвинених країн в питанні кредитування малого підприємництва. А саме:

тних послуг;

- підвищення рівня пропозицій мікрокреди-

- створення в банківських установах відповідних структурних підрозділів, які б займалися лише вивченням попиту на мікрокредити та обслуговуванням даного сектору;

- більш активно фінансувати підприсмства, які використовують енергозберігаючі технології;

- введення розумних відсотків;

- збільшення термінів кредитування.

У свою чергу державі необхідно здійснити ряд заходів, спрямованих на підтримку та розвиток сфери малого бізнесу. Основними 3 них, на нашу думку, можуть бути наступні:

- нагляд та регулювання діяльності банків в сфері надання кредитів малому та середньому підприємництву;

- сприяння більш ефективному кредитуванню підприємств, які експортують продукцію, або ж випускають таку, яка зменшує імпорт;

- участь в фінансуванні малих та середніх підприємств небанківських установ;

- розробляти загальнодержавні та регіональні програми щодо кредитування малого та середнього бізнесу небанківською системою (наприклад, в Японії - Фінансова корпорація малого бізнесу, в США Адміністрація малого бізнесу SBA);

- сприяння надання акціонерного капіталу для малого та середнього бізнесу;

- створення передбачуваного, прозорого та економічно-обгрунтованого нормативно-правового поля у сфері підприємницької діяльності.

Наразі в Україні діють такі програми підтримки суб' Єктів малого та середнього підприємництва, що реалізуються банківськими установами:
- «Спільна 3 Свропейським інвестиційним банком Програма кредитування МСП та установ із середньою капіталізацією». У рамках угоди між публічним акціонерним товариством «Державний експортно-імпортний банк України» (АТ «Укрексімбанк») та Європейським інвестиційним банком (СІБ) кредитуються українські підприємства малого та середнього бізнесу, проекти у галузі енергоефективності, охорони довкілля та інші пріоритетні проекти розвитку місцевого приватного сектору, подолання наслідків змін клімату та адаптації до них тощо;

- «Програма сприяння кредитуванню малого та середнього бізнесу (Програма Кредитної установи для Відбудови (ФРН) (КфВ)». Програма КфВ призначена для суб'єктів господарської діяльності, юридичних осіб і фізичних осіб-підприємців, та реалізується для сприяння кредитуванню малого та середнього бізнесу з метою розширення обсягів виробництва, покращення якості та розширення асортименту продукції, підвищення продуктивності праці та створення нових робочих місць шляхом фінансування інвестиційних проектів за рахунок ресурсів КфВ;

- «Програма Кредитування спільно 3 Європейським інвестиційним банком». Між АТ «Ощадбанк» та ЄІБ було укладено фінансову угоду, основна мета якої - фінансування вітчизняних малих та середніх підприсмств, компаній середньої капіталізації та інших пріоритетних проектів.

Висновки та рекомендації щодо подальших досліджень. Не дивлячись на складну економічну ситуацію в нашій державі, середне та мале підприємництво прагне розвитку. А для цього необхідне фінансування. Розглядати внутрішнє фінансування, як основне джерело надходження коштів, не має сенсу. Адже у вітчизняних підприємців немає великих прибутків. I основним джерелом фінансування стає зовнішнє. Дехто шукає партнерів та інвесторів, але все ж більшість звертається до банківських установ за позиками. При цьому підприємці зіштовхуються 3 багатьма проблемами: великі відсоткові ставки, короткий термін кредитування, небажання банків співпрацювати 3 початківцями в бізнесі, відсутність початкового капіталу, жорсткі умови кредитування тощо. Все це стримує розвиток підприємництва. Отже, на нашу думку, для ефективного розвитку та діяльності малого та середнього бізнесу необхідно впроваджувати такі заходи: введення розумних відсотків, збільшення термінів кредитування, підвищення рівня пропозицій мікрокредитних послуг, участь в фінансуванні небанківських установ, сприяння більш ефективному кредитуванню підприємств, які експортують продукцію, або ж випускають таку, яка зменшує імпорт, введення загальнодержавних та регіональних програм щодо кредитування малого та середнього бізнесу, створення прозорого та економічно-обгрунтованого нормативно-правового поля у сфері підприємницької діяльності.

Питання кредитування малого та середнього бізнесу в наш час дуже актуальне, і тому його пот- 
рібно досконало вивчати та досліджувати. Адже вдосконалення цього процесу дасть можливості для роз- витку малого та середнього бізнесу, а це в свою чергу призведе до розвитку економіки країни вцілому.

\title{
Література
}

1. Чайковський Я.І. Кредитування малого і середнього бізнесу як чинник вирішення проблем зайнятості населення / Я. Чайковський // Регіональні аспекти розвитку і розміщення продуктивних сил України : зб. наук. праць каф. управління трудовими ресурсами і розміщення продуктивних сил Терноп. акад. нар. госп-ва. Тернопіль, 2004. - № 9. - С. 224-228.

2. Статистичні дані Державного комітету статистики України [Електронний ресурс]. - Режим доступу: www.ukrstat.gov.ua

3. Звіт Національного банку України [Електронний ресурс]. - Режим доступу: https://www.bank.gov.ua

4. Лащ Т.А. Проблеми банківського кредитування малого підприємництва / Т.А. Лащ // Економічний простір. - 2009. - №23/1. - С.155-165.

5. Бохенко О.С. Вінницький торговельно-економічний інститут КНТЕУ Проблеми кредитування малого та середнього бізнесу [Електронний ресурс] / Бохенко О.С., Бурлуцька Ю.М., Столярчук Г.М. - Режим доступу: http://www.rusnauka.com/11_EISN_2010/Economics/63993.doc.htm

6. Островська А. Ю. Проблеми та шляхи вдосконалення банківського кредитування [Електронний ресурс] / А. Ю. Островська. - Режим доступу:

http://www.rusnauka.com/17_AVSN_2012/Economics/1_113289.doc.htm

7. Рейтинги банківських послуг [Електронний ресурс]. - Режим доступу: http://www.bankchart.com.ua

8. Воротіна Л.І. Малий бізнес та підприємництво як засіб адаптації до ринкових форм господарювання / Л.І.Воротіна. - К.: Знання України. - 1996. - С.4-17

9. Євтух О.Т. Кредит як соціально-економічне явище / О.Т. Свтух // Фінанси України. - 2006. - № 3. C.7-21.

10. Загородній А. Фактори, що визначають розвиток малого бізнесу в Україні / А.Загородній, Л. Гром’як // Економіка України. -1996. - №5. - С.65-67.

Стаття надійшла 20.10.2016

Стаття прийнята до друку 3.11.2016

Доступно в мережі Internet 30.12.2016

\author{
Мартыновский В.C. \\ кандидат экономических наук, доцент \\ E-mail: martinv@i.ua \\ Бурага Л.С. \\ магистрант \\ кафедра экономики промышленности \\ Одесская национальная академия пищевых технологий \\ ул. Канатная, 112, м. Одеса, Украина, 65039 \\ E-mail: mila.buraga@yandex.ru
}

\section{ЭФФЕКТИВНОСТЬ БАНКОВСКОГО КРЕДИТОВАНИЯ МАЛОГО И СРЕДНЕГО БИЗНЕСА В УКРАИНЕ}

Малый и средний бизнес в Украине составляет 99\% всех субьектов хозяйствования. Но в то же время эта сфрера остро нуждается в финансировании. В данной статье рассмотрен один из источников получения средств, а именно, банковское кредитование. На сегодняшний день банки проявляют больший интерес к кредитованию данного сегмента рынка, о чём свидетельствует постепенное увеличение количества банков, предоставляющих специальные услуги для малого и среднего бизнеса, и ежегодное увеличение общей суммы выданых кредитов банками( по данным НБУ). Основными видами деятельности, которые больше всего кредитуются, являются оптовая и розничная торговля, а также перерабатывающая промышленность. Это те отрасли, которые приносят больший доход, и быстро окупаются. Кредитование в агропромышленную и пищевую отрасли очень мало. Это связано с нежеланием предпринимателей заниматься таким трудоемким и малодоходным бизнесом.

Кредитование малого и среднего бизнеса в Украине емеет ряд проблем, среди которых: высокие процентные ставки, короткий срок кредитования, отсутствие у начинающего предпринимателя 
начального капитала, и т.д. В решении этих проблем необходимо активное участие как государства так и банковских учреждений.

Ключевые слова: малый и средний бизнес, банковские кредиты, статистика НБУ, проценты, финансирование, государственная поддержка.

\author{
Martynovsky V. \\ Ph.D. in Economics, Associate Professor \\ E-mail: martinv@i.ua \\ Buraha L. \\ Undergraduate \\ Department of Industrial Economics \\ Odessa National Academy of Food Technologies \\ Kanatna str., 112, Odessa, Ukraine, 65039 \\ E-mail: mila.buraga@yandex.ru
}

\title{
EFFICIENCY CREDIT OF BANKING FOR SMALL AND MEDIUM BUSINESS IN UKRAINE
}

Small and medium business in Ukraine is $99 \%$ of all business entities. But at the same time, it is in need of funding very much. In this article, discusses one of the sources of funds, namely, bank lending. Today banks are showing greater interest in lending to this segment of the market, as evidenced by the gradual increase in the number of banks that provide special services for small and medium-sized businesses, and the annual increase in the total amount of credits banks (according to the NBU data). The main activities of the most credited are the wholesale and retail trade, as well as the processing industry. These are sectors that generate more income and quickly pay for themselves. Lending to agricultural and food industry is very small. It is connected with the reluctance of entrepreneurs to engage in such a labor-intensive and unprofitable business.

Lending of small and medium-sized businesses in Ukraine has a number of problems, among which are: high interest rates, short-term lending, the lack of a beginning entrepreneur start-up capital, etc. For solution of these problems required active participation of both the state and banking institutions.

Keywords: small and medium businesses, bank loans, NBU statistics,

interest, funding, state support.

\section{References}

1. Chaikovskyi, I. I. (2004). Kredytuvannia maloho i serednoho biznesu yak chynnyk vyrishennia problem zainiatosti naselennia. Rehionalni Aspekty Rozvytku I Rozmishchennia Produktyvnykh Syl Ukrainy, 224-228.

2. Statystychni dani Derzhavnoho komitetu statystyky Ukrainy. Retrieved October 10, 2016, from http://ukrstat.gov.ua

3. Zvit Natsionalnoho banku Ukrainy. Retrieved October 10, 2016, http://.bank.gov.ua

4. Lashch, T. A. (2009). Problemy bankivskoho kredytuvannia maloho pidpryiemnytstva. Ekonomichnyi Prostir, 155-165.

5. Bokhenko, O. S. (2010). Problemy kredytuvannia maloho ta serednoho biznesu. Retrieved October 10 , 2016, from www.rusnauka.com/11_EISN_2010/Economics/63993.doc.htm

6. Ostrovska, A. I. (2012). Problemy ta shliakhy vdoskonalennia bankivskoho kredytuvannia. Retrieved 2016, from http://www.rusnauka.com/17 AVSN 2012/Economics/1 113289.doc.htm

7. Reitynhy bankivskykh posluh. (2015). Retrieved 2016, from http://www.bankchart.com.ua

8. Vorotina, L. I. (1996). Malyi biznes ta pidpryiemnytstvo yak zasib adaptatsii do rynkovykh form hospodariuvannia. K.: Znannia.

9. Ievtukh, O. T. (2006). Kredyt yak sotsialno-ekonomichne yavyshche. Finansy Ukrainy, 7-21.

10.Zahorodnii, A., \& Hrom'iak, L. (1996). Faktory, shcho vyznachaiut rozvytok maloho biznesu v Ukraini. Ekonomika Ukrainy, 5, 65-67. 